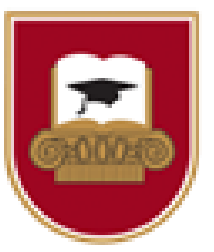

Vadyba

\title{
PORT CUSTOMS BROKERAGE SERVICES: PARTIAL RECONCEPTUALIZATION OF THE COMPANY
}

\author{
Saulius Lileikis, Greta Staniūtè \\ Lithuanian Maritime Academy
}

\begin{abstract}
The activities of the chosen company providing customs brokerage services at Klaipeda State Seaport must be at least partially reconceptualized by updating the current concept of the company's operations in order to retain its customers and attract new ones, as competition grows. This requires the identification of the problem areas of the company's activities and the provision of opportunities for their solutions. Partial reconceptualization of the customs brokerage company begins with generation of business ideas. The customs brokerage company should update its services in terms of quality and time. The quality of services could be improved if the customs brokerage company at Klaipeda State Seaport provided not only usual customs brokerage services but also the brokerage services in International Logistics Channels. More customers would choose the company that operates $24 / 7$ because this would speed up the transportation of goods. Partial reconceptualization of the customs brokerage company includes changing the working time and purposeful staff training in order to provide new services.

KEYWORDS: port; customs; brokerage; reconceptualization; services.
\end{abstract}

\section{Introduction}

Relevance and novelty of the research. The activities of the chosen company providing customs brokerage services at Klaipeda State Seaport must be at least partially reconceptualized by updating the current concept of the company's operations in order to retain its customers and attract new ones, as competition grows. This requires the identification of the problem areas of the company's activities and the provision of opportunities for their solutions.

This kind of problem is explored from a global perspective in various aspects by analyzing theories on the transformation of organizational performance (Valackienè 2012; Burke 2014; Anderson 2015; Burke, Noumair 2015; Matulyte 2015; McGuire, Palus, Pasmore, Rhodes 2015; Berends, Smits, Reymen, Podoynitsyna 2016; Carballo, Graziano, Schaur, Martincus 2016; Gwardzinska 2016; Bočkuté, Danylivaitė 2017; Jurkaitienè, Kiyak, Bružaitè 2017; Chalendard, Raballand, Rakotoarisoa 2019), which may be adapted to partial reconceptualization of the activities of the company providing port customs brokerage services.

The object of the research is port customs brokerage services.

The subject of the research is opportunities for partial reconceptualization of the company's activities.

The purpose is to conduct an investigation of attractiveness of the chosen company providing customs brokerage services at Klaipeda State Seaport in order to partially reconceptualize its activities.

\section{Methodology and organization of the research}

The two main methods used are as follows:

- Structured interview (expert method) is used when interviewing freight forwarders about the customs brokerage services in order to provide hypothetical opportunities for partial reconceptualization of the company's activities (the expert method includes experts who are business customers of the customs brokerage company and use its services on a daily basis);

- Hypothetical modeling of partial reconceptualization of the company's activities.

Factors contributing to the validity of this study are the following:

- Adaptation of customs brokerage theories to the interview questionnaire;

- The sample size is 20 freight forwarders (representativeness is 100\%);

- The sample is homogeneous because all interviewees are employees of the same logistics company;

- Research ethics ensuring greater reliability of responses.

The research tool is a questionnaire consisting of 4 chapters covering the following topics:

- Current concept of activities of the customs brokerage company;

- Generation of new business ideas;

- Formulation of a new concept of the company's activities;

- Realization of a new concept of the company's activities. 
The interview questionnaire consists of 20 questions based on 4 topics listed above, which is applied in order to investigate the activities of the company providing customs brokerage services.

The study was conducted in May 2019.

The basic methodological principle is progressivism, which emphasizes the creative development of activities and serves as the basis for the idea of partial reconceptualization of the company providing customs brokerage services at Klaipeda State Seaport.

The type of the research is descriptive.

The limits of the research indicate that its results may only be applied to the activities of the chosen company providing customs brokerage services.

\section{Peculiarities of customs brokerage activities}

A customs broker is an economic entity of the Republic of Lithuania, which in the established manner has received the right to provide customs brokerage services. A customs broker representative means a founder (stockholder), head of administration or employee whose qualification was approved in the established manner and who is included in the list of representatives of the customs broker and has the right to provide customs brokerage services.

Customs brokerage services are provided in accordance with the written contract concluded with a person or in accordance with the person's written mandate for a fee or free of charge (it is specified in the written contract). A customs broker represents a person at customs clearance by acting on behalf of the person in his/her interests or acts as a mediator at customs clearance acting on behalf of its own and on behalf of the person.

Customs brokers help customers complete general administrative documents of import, export and transit procedures. They complete and draw up other international documents of cargo transportation, i.e. CMR waybills and TIR Carnet declarations, including electronic ones.

At the customer's request, customs brokers:

- Carry out various customs procedures;

- Submit requests;

- Take samples of goods;

- Prepare certificates of origin of goods;

- Receive certificates of origin of goods (Customs Brokerage Rules 2002).

A TIR Carnet is a document issued by the TIR Association that is used to transport the goods from the European Union to third countries. The TIR Carnet is also used for the international transportation of goods. It guarantees international delivery of goods from the consignor to the recipient. The TIR Carnet is issued to carriers who are members of the TIR Carnet Association. Preparation and submission of TIR Carnet electronic data is a service during which an electronic document is completed and uploaded to the customs system (Baublys 2016).

According to the CMR Convention, a CMR waybill approves the contract of carriage of goods and regulates liability for damage caused during transportation. In case of litigation, a duly completed CMR waybill is proof of the fact that the goods have been transferred to the carrier.

This document also confirms that transportation is performed in accordance with the requirements of the CMR Convention. It is important to know that in crossborder disputes, the provisions of the CMR Convention take precedence over national law.

The exporter is the person established in the customs territory of the Union who is, at the time of acceptance of the declaration, a party to the contract concluded with a consignee in a third country. The exporter has the right to decide whether the goods must be transported to a destination outside the customs territory of the Union.

The export procedure shall be applied when Union goods are taken out of the customs territory of the Union to third countries or into special fiscal territories. Under the export procedure, an electronic export declaration must be lodged. Any person who wishes to import goods from third countries must have an EORI number and be registered in the Customs Debtors Register. Goods brought into the customs territory of the Union must be stated in the general declaration of entry, which shall be submitted by the carrier. The general declaration of entry is provided to the first customs office of entry within a specific period prior to the entry of the goods into the customs territory of the Union.

After Lithuania's accession to the European Union, international road transportation continues under the TIR transit procedure. This procedure is applicable in accordance with the Customs Convention on the International Transport of Goods under Cover of TIR Carnets (TIR Convention). The TIR transit procedure is carried out using a TIR Carnet, which is both a customs declaration and a guarantee. After Lithuania's accession to the European Union, goods transported using a TIR Carnet may be transported only if their transit route passes through the territory of a third country (Sarapinienè, Avižienis 2008).

The general transit procedure is applied to the goods that are transported between the countries of the European Union and the countries of the European Free Trade Association: Iceland, Norway, Switzerland, and Liechtenstein. This procedure is carried out in accordance with the Convention on Common Transit.

In the case of common transit, the $\mathrm{T} 1$ or $\mathrm{T} 2$ procedures shall be applied, depending on the status of the goods transported (Community goods or nonCommunity goods).

The following documents are used in a procedure of continuous activities:

- A general administrative document;

- A transit accompanying document or accompanying document of transit and/or security to which a list of the goods or the list of transit and/or security goods is added, if needed.

The client under the customs brokerage service agreement is represented at customs. A customs broker prepares the documents and physically represents the client during cargo inspection and communicates with customs officials.

Customs brokers represent customers (clients) at the Territorial Customs or Customs Department, i.e. they:

- Submit requests; 
- Obtain permits;

- Extend the transit period;

- Receive explanations concerning the customs procedures or customs-approved actions and the classification of goods;

- Present samples of goods to the customs laboratory;

- Provide guarantees for import and transit procedures;

- Advise on customs procedures and customs authorized activities;

- Determine customers' needs;

- Advise them on the choice of the intended customs procedure, etc. (Customs Brokerage Rules 2002).

The company's specificity must be taken into account in order to partially reconceptualize its activities concerning customs brokerage services. It must start with intellectual activity generating new ideas. It is necessary to rethink the concept of a customs brokerage company and update the mission and vision of its activities. Partial reconceptualization of company's activities does not make sense if it is only at the level of ideas and concepts. They need to be implemented. Reconceptualization of the company's activities needs management control in order to realize everything properly. Management control is crucial in achieving new goals.

In addition, it is important to consider two aspects of reconceptualization, i.e. reorganization and restructuring:

- The first objective is a new business model through reorganization of activities of the company that provides customs brokerage services;

- The second objective is a new adaptive structure of an organization through restructuring of its activities.

The key steps in the company's reconceptualization process in accordance with the theories (Burke 2014; Anderson 2015; Matulyte 2015; McGuire, Palus, Pasmore, Rhodes 2015) are as follows:

- Rethinking new services and potential customers;

- Rethinking the mission and vision of a company;

- Strategic and tactical marketing plan.

It is necessary to regularly change some activities in order to ensure fast provision of high-quality customs brokerage services. A customs brokerage company must be competitive in a changing market. Therefore, it must take into account the needs and wishes of its customers. All of this can be accomplished by partially reconceptualizing the activities of the chosen customs brokerage company.

The company's reconceptualization should begin with individual and collective rethinking of its relevant issues. New ideas need to be generated in order to improve services provided by the company. Customs brokerage services may be improved in terms of time, cost, and quality.

Typically, most small companies providing customs brokerage services are limited to export, import and transit procedures. However, they may provide not only individual, i.e. specific services, but also other services that are not prohibited by law.

Customs brokers gradually become economic entities providing logistics services:

- Customs brokers become insurance agents or insurance brokers;

- Freight forwarders become customs brokers;
- Founders of a customs warehouse become insurance brokers (agents).

It is one of the most important changes in the activities of customs brokers in Lithuania. This makes it easier for customs brokerage companies to compete with similar companies.

Customs brokers very often operate only in their own country. This is an inconvenience to entities of International Logistics Channels who use their services. Mediators of International Logistics Channels are not usually required for the transportation of goods and insurance or provision of other logistics services in transit countries. The opposite happens in the case of customs brokerage services. It is necessary to look for persons who will carry out the mandatory customs formalities in each country. Lithuanian customs brokers and other entities, e.g. from neighboring countries, should develop international cooperation in order to carry out the customs formalities and commit to customers to carry out the customs formalities in International Logistics Channels or at least in its separate stages.

Another untapped opportunity for customs brokers' activities is to complete the customs formalities by using both possible forms of customs representation. Some clients, especially from other countries, would certainly benefit from indirect customs representation provided by customs brokers. The right of representation is provided for in the Community Customs Code. Each person may appoint his/her representative who is authorized to represent him/her at customs by carrying out the acts prescribed by the customs rules.

Representation may be:

- Direct when a representative acts on behalf of another person and in his/her interests;

- Indirect when a representative acts in his/her own name but on behalf of another person (Community Customs Code).

Only customs brokers have the right to directly represent other persons in the customs by submitting a customs declaration in the customs territory of the Republic of Lithuania. This is stipulated in the Law on Customs of the Republic of Lithuania.

As regards the reconceptualization of activities, the fact that most clients need a customs broker to work 24/7 should be taken into account. Most small customs brokerage companies are open from $8 \mathrm{am}$ to $5 \mathrm{pm}$. Customers who transport goods prefer to use their time more productively without having to wait for a customs broker, e.g. until the morning of the next day if there was a problem by getting the goods ready in the evening.

It is necessary to change the business concept in order to improve the services of a customs broker. A new mission and vision needs to be defined by formulating new goals and objectives. They should be implemented systematically. It is important to consider the innovation lifecycle, which includes:

- Generation of ideas;

- Creation of innovation;

- The spread of innovation;

- The use of innovation.

A marketing plan needs to be developed in order to successfully reconceptualize the company's activities in accordance with new ideas. A new marketing plan 
enables the search for new customers and retention of the existing loyal ones.

\section{Possibilities of partial reconceptualization of the company's activities}

Service quality must be maintained in order to attract new customers and retain the existing ones. The research has identified the problem areas and provided opportunities for partial reconceptualization of the company, which would allow carrying out the tasks provided for by the organization's strategy more appropriately and efficiently in terms of time.

The problem areas identified in the evaluation of the company's activities hinder the smooth operations of the customs broker. The opportunities for improving customs brokerage services have been provided in order to solve the problem areas. The hypothetical model for partial reconceptualization of the company's activities is presented below (Fig. 1).

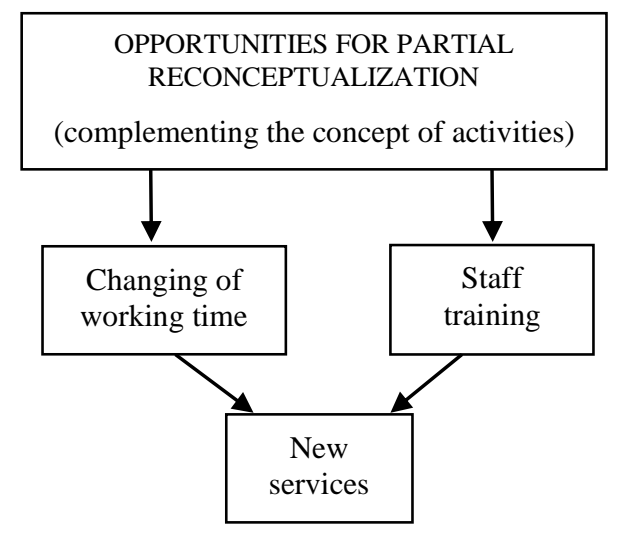

Fig. 1. The hypothetical model of partial reconceptualization

The direction of the arrows in the figure shows that the opportunities of the company's partial reconceptualization include changing of working time and staff training in order to provide new services of high quality. It is necessary to attract new customers.

The theoretical principles of the concept of the company's activities must be taken into account when carrying out partial reconceptualization of the chosen company's activities. Existing operating principles of the company are not sufficient in this case to retain the existing customers and find new ones. Complementing the list of principles and activities is necessary when renewing the concept of the company.

The study and responses of the interviewees have indicated that the first problem area of the company's activities is short working hours. The interviewees $(100 \%)$ said that they would be satisfied and encouraged to continue being loyal customers if the working hours of the managers (declarants) were not from 9am to $5 \mathrm{pm}$ but that they were available 24/7. Drivers' downtime in case of problems that can only be solved by managers (declarants) would be avoided by changing the principle of working hours.

Such kinds of situations are often encountered when unforeseen problems occur with the freight carrier at the Border Crossing Post after 5pm. In this case, drivers must wait until 9am of the next day when managers (declarants) begin their work and can help solve the problem because, until the problem is resolved, the freight carrier cannot leave the territory of Lithuania.

The mentioned operating principle, i.e. working hours, needs to be changed, so that the freight carrier can contact the managers (declarants) quickly concerning the problems in order to avoid unnecessary downtime for him/her and deliver the cargo to the right place as soon as possible. Nevertheless, longer working hours would not only help to retain existing customers but the company would be more attractive to new ones.

The second problem area, which is a very important principle of the company's activities, is purposeful staff training. It is necessary to constantly adapt to change in order to continuously provide quality services.

Customs brokerage activities are carried out using electronic programs. These electronic programs are regularly updated. Thus, employees of the chosen company that provides customs brokerage services must be made aware of the program updates. They can learn about the changes in the programs and how to use them only in seminars organized by the customs administration, during which it is consistently and clearly stated and displayed how new programs work and how one should use them for work.

Most of the interviewees $(90 \%)$ stated that continuous training of staff is essential. Updating of programs is related to legislation. The managers are able to work with new programs when they know everything that is relevant in relation to them. All the necessary information about using new programs is not published on the Internet or anywhere else. Thus, it is necessary to send managers to certain seminars, which are very important in ensuring the quality of their work.

The interviewees pointed out the third very important principle of the concept of the company, which needs to be updated and expanded with new services. The interviewees $(100 \%)$ said that the company should provide new services, such as a completion of the export procedures and use of the Freight and Goods Information System. These changes would encourage customers to remain loyal and make the company more attractive to new prospective ones.

The Freight and Goods Information System has been installed at Klaipeda State Seaport. This System is intended for transmission and processing of the information about cargoes transported through Klaipeda State Seaport. The export procedure shall be applied where the Union's goods leave the customs territory of the Union to third countries or to special fiscal territories. When goods are exported from Lithuania and the European Union, the export documentation must be submitted to the controlling customs office. This documentation is prepared by the manager (declarant). This is accompanied by an electronic export declaration (delegated act).

The documentation required for the export procedure shall be completed and prepared as follows:

- The general administrative document shall be completed in accordance with the current export documentation procedure; 
- Transport documents are prepared for the goods transported by road and rail internationally (CMR, TIR Carnet, SMGS waybills);

- Other documents accompanying the cargo shall be arranged.

Currently, the Freight and Goods Information System is used by more than 460 companies and government agencies operating at Klaipeda State Seaport. Thus, the company needs to consider a new service - working with the Freight and Goods Information System when updating its business concept. The company would become more attractive to new customers and should be stable in the face of growing competition.

The Freight and Goods Information System would be beneficial for the company because the exchange of electronic data at Klaipeda State Seaport would simplify and speed up the process of cargo transportation through the port. This system allows eliminating the flow of many paper documents operating between ship agencies, freight forwarders, stevedoring companies, customs offices and other state authorities that control cargo and goods. These documents include various import, export, transshipment permits, stowage certificates, quality certificates and the like.

Managers (declarants) as well as forwarders, agents and stevedoring companies would not waste time because they would be able to receive and submit electronic documents to one another and to public authorities through a single access point.

The Freight and Goods Information System would enable customs and the customs brokerage company to obtain not only prior information and documentation for risk assessment but also operational and statistical information on cargo at the seaport. In addition, the utilization of the system's capacity would facilitate the control of port stevedoring and shipping operations and the provision of higher quality public services.

\section{Conclusions}

Partial reconceptualization of the customs brokerage company begins with generation of business ideas. The customs brokerage company should update its services in terms of quality and time. The quality of services could be improved if the customs brokerage company at Klaipeda State Seaport provided not only usual customs brokerage services but also the brokerage services in International Logistics Channels. More customers would choose the company that operates $24 / 7$ because this would speed up the transportation of goods. Partial reconceptualization of the customs brokerage company includes changing the working time and purposeful staff training in order to provide new services and attract new customers.

\section{References}

Anderson, D. (2015). Organization Development: The Process of Leading Organizational Change. Sage, London.

Baublys, A. (2016). Kroviniu vežimas. Technika, Vilnius.

Burke, W. (2014). Organization Change: Theory and Practice. Sage, London.

Burke, W. and Noumair, D. (2015). Organization Development: A Process of Learning and Changing. Pearson FT Press, New Jersey.

Berends, H., Smits, A., Reymen, I. and Podoynitsyna, K. (2016). Learning while (re)configuring: Business model innovation processes in established firms. Strategic Organization, 14(3), 181-219 [revised 202001 20], $<$ https://journals.sagepub.com>.

Bočkutè, I. and Danylivaite, A. (2017). Technologinès veiklos koncepcijos palyginimas: krovinių ekspedijavimo įmonių jūrų transporto srityje atvejis. Inžineriness ir edukacinès technologijos, 1, 15-20 [revised 202001 27], <http://www.ktk.lt>.

Carballo, J., Graziano, A., Schaur, G. and Martincus, C.V. (2016). Endogenous Border Time: Ports, Customs, Storage. CESifo GmbH, Munich.

Chalendard, C.R., Raballand, G. and Rakotoarisoa, A. (2019). The use of detailed statistical data in customs reforms: The case of Madagascar. Development Policy Review, 37(4), 546-563 [revised 20200125$]$, $<$ http://documents.worldbank.org $>$.

Gwardzinska, E. (2016). Standardization of competencies and qualifications of customs representatives of the EU Member States. Customs, 6(1), 58-69.

Jurkaitienè, S., Kiyak, D. and Bružaite,, E. (2017). Verslo aplinkos veiksnių ịtaka ịmonių mokumui. Apskaitos ir finansu mokslas ir studijos: problemos ir perspektyvos, 11(1), 17-23 [revised 202001 27], 〈https://vb.kvk.lt>.

Matulyte, S. (2015). Rinkodaros strategijos taikymas, vertinimas ir jos tobulinimo galimybès analizé. Technologija, Kaunas.

McGuire, J., Palus, C., Pasmore, W. and Rhodes, G. (2015). Transforming Your Organization. Center for Creative Leadership, Washington.

Sarapinienè, S. and Avižienis, J.Š. (2008). Muitinès procedūros. MRU Leidybos centras, Vilnius.

Valackienè, A. (2012). Kriziu valdymas ir sprendimy priemimas. Technologija, Kaunas.

Saulius Lileikis, doctor of social sciences, associate professor at the Port Economics and Management Department of Lithuanian Maritime Academy. Directions of scientific interests: marine hodegetics and seaport anthropology. Scientific monographs: 1. Youth Altruistic Education: Socio-cultural Context. Socialization Perspective of the Personality (2007); 2. Methodology of Cultural and Psychosocial Maritime Education (2011); 3. The Outline of the Maritime Self-concept Development: Direction of the Personality Value (2015); 4. Maritime Leadership: Values, Psychology, Self-Development (2018). Address: I. Kanto str. 7, LT-92123 Klaipeda. Phone: +370 65208 106. E-mail: s.lileikis@lajm.lt

Greta Staniūtė, master's degree in Port and Shipping Management; scientific interests - port customs brokerage services. Address: I. Kanto str. 7, LT-92123 Klaipèda. Phone: +370 65208 106. E-mail: s.staniute@lajm.lt 
